\title{
VINCULAÇÃO PRÓPRIA SEM CONTRATO: A PUBLICIDADE E OS NEGÓCIOS PRELIMINARES NO CÓDIGO CIVIL/2002 E NO CÓDIGO DE DEFESA DO CONSUMIDOR.
}

Karime Costalunga ${ }^{7}$

Introdução; 1. A proteção do consumidor e o dever de informar nos negócios preliminares. A) A boa-fé objetiva e os negócios preliminares. B) A transparência e o dever de informar; II. A ruptura das negociações preliminares pela publicidade. A) A culpa in contrahendo e os novos tipos de vinculação sem contrato. B) A responsabilidade pela confiança despertada; Conclusão; Referências.

\section{INTRODUÇÃO}

Canaris ${ }^{2}$ bem percebeu o papel do Direito ao colocar que é modo de resolver casos concretos, do que conclui que sempre teve particular aptidão para aderir à realidade. Sendo assim, permite a seus aplicadores a utilização da ordem posta para a resolução de conflitos sociais dentro de uma regra admitida pelo corpo social como a mais justa para o caso. E, com apoio na reiterada experiência, conceito introduzido na doutrina brasileira por Miguel Reale $^{3}$, o legislador acabou concebendo o contrato, originado na realidade social.

Rudolf Von thering classificou o contrato como sendo a forma das relações de trocas ou, noutras palavras, o "concurso dos consentimentos (consensus) de duas pessoas ${ }^{4 \prime \prime}$. No contrato de compra e venda, por exemplo,

Pesquisadora de Direito de Familia e Sucessōes pela Escola de Direito de São Paulo da Fundaçáo Getulio Vargas (EDESP/FGV). Mestranda em Direito Privado pela Universidade Federal do Rio Grande do Sut.(UFRGS). Especialista em Processo Civil pela Universidade Federal do Rio Grande do Sul (UFRGS). Advogada.

2 CANARIS, Claus-Wilhelm. Pensamento sistemático e conceito de sistema na ciência do direito. 2 a ed, Lisboa: Calouste Gulbenkian, 1996, p. XXIV.

3 REALE, Miguel. Experiência e cultura. Campinas: Bookseller, 1999, p. 14. Para o brilhante jurista, "a experiência é o resultado de um processo histórico de experimentação que revela a dimensão histórica e temporal do direito". Op. cit., p. 21.

4 JHERING, Rudolf Von. A evolução do direito. Vertido da tradução francesa de O. de Meulenaere, por Abel D'Azevedo. Lisboa, J/Bastos, SD, 1971, p. 61. 
ocorre assunção por uma das partes de honrar com certo preço, para alcançar novo status jurídico - sinalagma - status de proprietário, enquanto a outra assume a obrigação de transferir um direito seu de propriedade, porque the é mais interessante ser credor. Entretanto, no contrato também acaba ocorrendo a transferência dos riscos, visando a segurança das partes na busca de seus objetivos.

Nesse cenário surgiu o Código de Defesa do Consumidor, tendo em vista que os remédios direcionados aos contratos tradicionais, vigentes à época, mostraram-se totalmente inadequados à proteção do consumidor, frente à explosão contratual. Antes de iniciar o discorrido, contudo, de perguntar: o individuo pode livremente retirar-se de negociações preparatórias de um contrato sem temer a prática de qualquer ato ilícito? A atualidade do problema da responsabilidade pré-contratual é decorrente da ruptura das negociações preliminares, durante as quais devem estar presentes os princípios da transparência e confiança entre ambos os contratantes, principalmente considerando o surgimento de novos negócios que ainda nāo tipificados.

Um dos exemplos mais claros em que é constatada a existência de uma relação contratual de fato, da qual também são decorrentes deveres, é nos casos de contato social entre as partes, bem como coloca Menezes Cordeiro:

A tais conjunturas, insusceptíveis de, num prisma dogmático, integrar a idéia de negócio, mas cujos efeitos desta se aproximam, pode-se bem chamar, aguardando melhor, de relaçōes contratuais de facto. A elas acolhem-se duas situaçōes: a dos contactos sociais típicos, próprios do tráfego nacional de massas, em que as pessoas se vāo encontrar investidas em ocorrências contratuais, seja qual for a sua vontade, apenas por assumirem comportamentos tipificados que, no decurso social, a isso conduzem: assim, por exemplo, no ingresso num transporte público ou numa auto-estrada sujeita a portagem. ${ }^{5}$

Esses deveres denominam-se deveres anexos de prestação, eis que preparam e asseguram a realização da prestação e o proveito posterior. São deveres de prestação menores, instrumentais, verdadeiros deveres de conduta ${ }^{6}$, consistentes, também, em um fazer (por exemplo, dever de informar), um não fazer (por exemplo, dever de guardar segredo) ou em um dar (por exemplo, dever de enviar manuais com instruções de uso) ${ }^{7}$. No período das negociaçōes

MENEZES CORDEIRO, António Manuel da Rocha e. Da boa-fé no direito civil. Coimbra: Almedina, 2001, p. 645 .

- SILVA, Clóvis Veríssimo do Couto e. A obrigação como processo. São Paulo: José Bushatsky, 1976.

7 MARQUES, Cláudia Lima. Vinculaçăo própria através da publicidade? A nova visão do Código de Defesa do Consumidor. In: Revista de Direito do Consumidor, 10, p. 09. 
preliminares de natureza de consumo, que acabam levando ou não à conclusão do contrato, o fornecimento das informações se efetivará através da oferta, que se constitui na concretização do dever de informar à contraparte pelo fornecedor.

O presente estudo tem por objetivo, portanto, investigar o problema resultante do rompimento abusivo das negociações preparatórias do negócio jurídico, principalmente de um contrato. Mais ainda: através do descortinamento do tema da publicidade no Direito do Consumidor, e uma vez constatada a informação ter sido prestada de maneira errônea, é de questionar se pode ela, mesmo assim, vincular os fabricantes ${ }^{8}$. O ponto de partida é uma premissa civil-constitucional para chegar à conclusão de que a sociedade mudou, mas, no entanto, deve continuar o contratante agindo com lealdade, probidade, correção. Parâmetros de operatividade da boa-fé serão traçados no objetivo de delimitar a interpretação tópico-sistemática, apontando a melhor solução ao caso concreto, em especial frente ao novo entendimento legislativo da oferta no novo Código Civil.

Na primeira parte, será examinado o caráter público das negociaçōes preliminares, que têm como centro toda e qualquer informação prestada ao consumidor. Vale dizer que, segundo Paulo Luiz Netto Lobo ${ }^{9}$, considerada a informação um dos pilares do direito do consumidor, principalmente na fase pré-negocial, o fornecedor deve respeitar seu dever de informar, de modo a oportunizar ao consumidor todo o acesso à informação. Mas referida conduta somente será possível àquele fornecedor que agir de boa-fé, e com base no princípio da transparência, seu derivado.

Na segunda parte do trabalho, para o mais aguçado exame do tema da publicidade, será necessário, sobremaneira, abordar a culpa in contrahendo originada na confiança que uma das partes acabou por despertar na outra, frente à real expectativa criada nesta última da efetiva contratação pelas negociações anteriores - e os tipos de vinculação sem contrato. A análise atenta de alguns casos de interpretação da jurisprudência, através do Código de Defesa do Consumidor e do Código Civil, desde o advento da nova ordem, que adotou o conceito de proposta, será de extrema utilidade para melhor abordagem da questāo.

s Vera Fradera, na tritha de Crisafull, classifica como fabricante "toda a pessoa, fisica ou jurídica, que produz, fabrica ou constrói, ou ainda, instala bens móveis de qualquer natureza, destinados a serem utilizados por outrem, consumidor, usuário ou fabricante, que transforma os referidos bens ou os incorpora em seus próprios produtos". CRISAFULL, Vincent. Le tisque RC produits du fabricant, en droit français, in Revue Trimmestriel de Droit Commerciel, Paris, France, n. 3u4 (juillet/décémbre), 1974, p. 28 e seguintes, apud FRADERA, Vera. O dever de informar do fabricante. In: Revista dos Tribu nais, 656, junho de 1990, pág. 53.

5 LÔBO, Paulo Luiz Netto. A informaçăo como direito fundamental do consumidor. In: Revista de Direito do Consumidor, 37 , p. 59. 


\section{I -A PROTEÇÃO DO CONSUMIDOR E O DEVER DE INFORMAR NOS NEGÓCIOS PRELIMINARES.}

Sem consumidor, não há sociedade de consumo; sem esta, não há mercado; e sem mercado, não há contratação massificada. Estudar e regular o status contratual do consumidor é, em último caso, afetar a grande maioria dos contratos firmados no cotidiano do mercado ${ }^{10}$. Os contratos no Código de Defesa do Consumidor têm como alvo a vulnerabilidade ${ }^{11}$ contratual do consumidor fenômeno jurídico, mas também econômico e social que leva o legislador a buscar formas de proteger o consumidor ope legis (esforço da tipologia - art. $4^{\prime \prime}$, I do $\mathrm{CDC}^{12}$ ). A tutela é alcançada ao consumidor em dois aspectos: na sua integridade físico-psíquica e, também, na econômica, mas sem, no entanto, descuidar da questão contratual, que se torna de enorme importância.

Ricardo Lorenzetti coloca que haverá vezes em que as partes até podem emitir corretamente sua declaração de vontade - o consentimento expresso, in casu -, mas a desigualdade econômico-social existente entre elas acaba inoportunizando o diálogo, as discussões ${ }^{13}$. Portanto, através da proteção de uma das partes ${ }^{\sharp 4}$, reestabelecendo o equilíbrio contratual, é buscada a igualdade real, se não de oportunidades, para que possam os agentes, em pé de igualdade, expressar seu consentimento. Ocorrerá, portanto, a alteração da correlação de forças, considerando que a fragilidade do consumidor irá se manifestar em três momentos principais: antes, durante e após a contratação propriamente dita. $O$ direito vem articulando diversas maneiras de amparar a parte mais fraca, sejam elas apenas de caráter cosmético ${ }^{15}$, informativo (relativo à publicidade) ou exigindo reflexão acerca do princípio da autonomia da vontade.

O Código de Defesa do Consumidor, ao romper com o pensamento individualista, da concepção clássica de contrato, e ao, automaticamente,

1 (4) MARQUES, Cláudia Lima. Contratos no código de defesa do consumidor: o novo regime das relações contratuais. 4a ed., rev., atuál, e ampl. São Paulo: Editora Revista dos Tribunais, 2002, p. 09.

"Alberto do Amaral jr. coloca que "os riscos decorrentes dos produtos e serviços oferecidos ao público são, em princípio, de responsabilidade do fornecedor, sendo esta a consequencia do princípio da vulnerabilidade do consumidor, aft. 4o, I do CDC". AMARAL JR., Alberto. O princípio da vinculação da mensagem publicitária. In: Revista de Direito do Consumidor, 14 , p. 50.

12 Art. 40 do CDC $(\ldots)$ - reconhecimento da vulnerabilidade do consumidor no mercado de consumo.

\$3 LORENZETTI, Ricardo Luis. Analisis crítico de la autonomia privada contractual, In: Revista de Direito do Consumidor, 14, p. 14.

i4 Lorenzetti ressalta que năo se leva em conta para a proteçăo da parte fragilizada sua condição como único contratante, e sim uma classe deles, como, por exemplo, os trabalhadores, os adquirentes e locadores de imóveis, os segurados, e, em geral, os consunidores. LORENZEFTI, Ricardo Luis. Analisis crítico de la autonomia privada contractual. In: Revista de Direito do Consumidor, 14, p. 14.

1. MARQUES, Cláudia Lima. Contratos no código de defesa do consumidor: o novo regime das relaçôes contratuais. 4a ed., rev, atual, e ampl. Săo Patlo: Editora Revista dos Tribunais, 2002, p. 10. 
positivar o princípio da funçāo social de contrato e o da boa-fé objetiva, cria novos conceitos e interpretações ao Direito. Referido ordenamento surgiu para auxiliar o Direito do Consumidor, do que faz parte, na evolução do pensamento jurídico, de modo que sua ratio irá garantir a eqüidade contratual, a válida manifestação de vontade, o pensamento tópico, a equivalência de prestações e a transparência e o respeito entre parceiros.

\section{A) A boa-fé objetiva e os negócios preliminares.}

Karl Larenz, ao tratar da boa-fé, coloca que contém um conceito valorativo, muito embora não seja uma questāo de avaliação subjetiva pela pessoa que decide, mas deve, sim, ser o intérprete e representante de todos aqueles que pensam de forma justa, de modo a orientar o seu juízo nas exigências geralmente existentes da justiça, que são concretizadas nos princípios gerais da ordem jurídica, no sentimento jurídico e nas opiniões sobre a lealdade do povo e dos grupos interessados ${ }^{16}$. Considerando, especificamente, a fase de formação contratual e da incidência do princípio da boa-fé, mister ressaltar a doutrina de Antonio Junqueira de Azevedo, que assim preleciona:

Como conseqüência da mudança de mentalidade, a recente lei de proteção do consumidor, que, por sua amplitude, é denominada "Código de Proteção ao Consumidor" (Lei 8.078/ 90) tem o princípio da boa-fé refletido em inúmeros de seus artigos. Aqui, trata-se, na verdade, da boa-fé objetiva que interessa na formação do contrato, isto é, a boa-fé como regra (objetiva de conduta) ${ }^{17}$.

Ruy Rosado de Aguiar Júnior ${ }^{18}$ coloca que a boa-fé é referida no Código de Defesa do Consumidor em duas passagens: a) no art. 4\%, que trata do atendimento das necessidades dos consumidore ${ }^{19}{ }^{19}$ o respeito à dignidade, à saúde e à segurança; a proteção de seus interesses econômicos; a melhoria de sua qualidade de vida, bem como a transparência e harmonia das relações de

16 LARENZ, Karl. Derecho Civil - Parte General. Trad de Miguel Izquierdo y Macias -Picavea. Madri: Edersa, 1978.

17 AZEVEDO, Antonio Junqueira de. A boa-fé na formaçāo dos contratos. In: Revista de direito do consumidor, 03, p. 79.

is AGUIAR JÚNIOR, Ruy Rosado de. A boa-fé nas relaçōes de consumo. In: Revista de Direito do Consumidor, 14, p. 21.

39 Eros Roberto Grau caracteriza o art 40 como norma objetiva, que define os fins da Politica Nacional das Relaçöes de Consumo, ou seja, define resultados a serem alcançados. GRAU, Eros Roberto. interpretando o Código de Defesa do Consumidor: algumas notas. In: Revista de Direito do Consumidor, 05, p. 183-189. 
consumo, atendendo princípios, dentre os quais a boa-fé ${ }^{20}$ nas relações entre fornecedores e consumidores; e b) no art. 51, ao elencar as cláusulas abusivas, quando afirma serem nulas de pleno direito as contratuais, dentre outras, relativas ao fornecimento de produtos ou serviços que coloquem o consumidor em desvantagem ou sejam incompatíveis com a boa-fé ou eqüidade ${ }^{21}$.

Por óbvio que os contratantes devem agir de acordo com a boa-fé, tanto na execução, quanto nas fases pré e pós-contratuais, mas de enorme relevância sua conduta no momento da formação do contrato - objeto deste estudo -, eis que a boa-fé e a transparência devem pautar o fornecimento de todas as informações necessárias para o livre juízo no período das tratativas. Menezes Cordeiro aborda uma regra de conduta, o dever de atuar segundo um grupo de deveres reconduzidos, ou seja, "uma regra geral de conduta segundo a boa-fé, concretizada em deveres de informação e lealdade ${ }^{22 "}$.

De enorme importância trazer à colação a conceituação de dever jurídico segundo Cláudia Lima Marques: "uma ordem ou comando dirigido pelo ordenamento jurídico ao indivíduo, a qual ele tem de observar como um imperativo, visando orientar seu procedimento ${ }^{23 "}$. Ainda, complementa a autora que a cada dever jurídico imposto a um indivíduo (devedor: lado passivo) corresponde um direito subjetivo assegurado a outro indivíduo ou ente (credor: lado ativo $)^{24}$. Ambas as partes devem respeitar os interesses da outra, auxiliando a contraprestação: o contratante deve evitar tudo o que poderia impedir ou dificultar a realização do contrato. Existe "uma 'obrigação' de cooperar, de informar, de se conduzir conforme e na direção da prestaçāo, não causando dano no patrimônio ou à pessoa do parceiro contratual ${ }^{25 "}$.

26 "Art. 40 CDC. A Política Nacional de Relaçöes de Consumo tem por objetivo o atendimento das necessidades dos consumidores, o tespeito a sua dignidade, saúde e segurança, a proteçào de seus interesses econômicos, a melhoria de sua qualidade de vida, bem como a transpatência e harmonia das relaçöes de consumo, atendidos os seguntes princípios:(..) 脽 - harmonizaçăo dos interesses dos participantes das relaçōes de consumo e compatibilizaçăo da proteção do consumidor com a necessidade do desenvolvimento econômico e tecnológico, de modo à viabilizar os princípios nos quais se funda a ordem econômica (art. $170 \mathrm{CF}$ ), sempre com base na boa-fé e equilibrio nas relaçöes entre consumidores e fornecedores". (grifo nosso)

21 "Art. 51 CDC. São nulas de pleno direito, entre outras, as cláusulas contratuais relativas ao fornecimento de produtos e serviços que: (...).IV - estabeleçam obrigaçöes consideradas iniquas, abusivas, que coloquem o consumidor em desvantagem exagerada, ou sejam incompativeis com a boaté ou a eqüidade".

22 MENEZES CORDEIRO, António Manuel da Rocha e. Da boa-fé no direito civil. Coimbra: Almedina, 2001 , p. 641 .

23 MARQUES, Cláudia Lima. Vinculaçăo própria através da publicidade? A nova visăo do Código de Defesa do Consumidor. In: Revista de Direito do Consumidor, 10, p. 07.

24 MARQUES, Cláudia Lima. Vinculação própria através da publicidade? A nova visăo do Código de Defesa do Consumidor. In: Revista de Direito do Consumidor, 10, p. 07

25 MARQUES, Cláudia Lima. Vinculação própria através da publicidade? A nova visão do Código de Defesa do Consumidor. In: Revista de Direito do Consumidor, 10, p. 08. 
Quanto à conceituação dos atos negociais, segundo a doutrina de Orlando Gomes, foi prevista a definição de negócio jurídico estreitamente conectado à autonomia privada ${ }^{26}$. Ocorre que, com o evoluir do contato social e com a conseqüente decadência do voluntarismo ${ }^{27}$, a natureza dos atos acabou se alterando e, portanto, negócios jurídicos passaram a envolver inúmera categoria de atos, divorciados do dogma da vontade ${ }^{28}$. A partir do momento em que os negócios jurídicos vêem vinculada a parte por seu comportamento, a definição mais adequada à espécie passa a ser "o ato de autonomia privada que empenha o sujeito que o pratica, a ter conduta conforme ao regulamento dos seus interesses fixado com a prática do ato $^{29 \prime}$. Nessa esteira, Antonio Junqueira de Azevedo coloca que a caracterização do negócio jurídico é a manifestação de vontade qualificada por circunstâncias que levam seja visto socialmente como direcionado à produção de efeitos jurídicos:

Depois, o direito, acompanhando a visão social, atribui, a essa declaração, efeitos, em correspondência com os efeitos manifestados como queridos (efeito constitutivo de relações jurídicas - característica secundária), mas, já então, somente desde que, in concreto, haja os demais pressupostos de existência, e, ainda principalmente, os de validade e eficácia. ${ }^{30}$

Mister, também, abordar as diferenças entre as negociações preliminares e os contratos preliminares - também denominados prém contratos ${ }^{31}$. Estes são convenções pelas quais alguém se obriga a celebrar, futuramente, certo contrato. Ainda, segundo a doutrina de João Calvão da Silva, "o contratompromessa é a convenção pela qual alguém se obriga a celebrar certo negócio jurídico ${ }^{32 . "}$.

26 Betti conceituou autonomia privada como sendo a "autoregulação dos interesses particulares". Destaca, entretanto, que a autonomia privada é reconhecida pela ordem juridica com certos limites. BETT, Emilio. Teoria general del negocio jurídico. Trad. espanhola, Ed. Rev. de Derecho Privado, Madri, p. 40.

27 GOMES, Oriando. Transformações gerais do direito das obrigaçôes. 2a ed., aument., São Paulo: Editora Revista dos Tribunais, 1980 , p. 65.

28 GOMES, Orlando. Transformações gerais do direito das obrigaçóes. 2a ed., aument., São Paulo: Editora Revista dos Tribunais, 1980, p. 65.

29 A doutrina abandona a conceituação de ato juridico como sendo "a declaraçăo de vontade destinada a produzir efeitos juridicos". Vałe dizer que a investigaçāo do intento do agente não mais representa é imprescindivel, cedendo espaço às idéias de auto-responsabilidade e confiança dos outros 5 ujeitos. COMES, Orlando. Transformaçôes gerais do direito das obrigações. 2a ed., aument., São Paulo: Editora Revista dos Tribunais, 1980, p. 71.

30 AZEVEDO, Antônio Junqueira de. Negócio jurídico - existência, validade e eficácia. 4a ed., atual. de acordo com o novo Código Civil (Lei n. 10.146, de 10.01.2002). São Paulo: Saraiva, 2002, p. 124 e segs.

31 "O pré-contrato é comuníssimo no Brasil. Em 99,9\% dos casos de vendas de imóveis, antes do contrato définitivo, é feito um contrato pré-contrato ou 'promessa' de compra e venda, com previsão do pagamento do preço em parcelas (e a escritura pública de venda e compra somente é feita após o pagamento integral do preço)". AZEVEDO, Antonio lunqueira de. A boa-fé na formação dos contratos. In: Revista de Direito do Consumidor, 03, p. 84 .

32 SHLVA, João Calvão da. Sinal e contrato promessa. 9a ed, Coimbra: Almedina, 2002, p. 15. 
Através dele, os contratantes se certificam do cumprimento do futuro contrato e fixam o seu conteúdo, obrigando-se a celebrá-lo, sem, contudo, procederem à imediata conclusão. Conclui referido autor que o contratompromessa ${ }^{33}$ - ou précontrato - é verdadeiro contrato, distinto do contrato subseqüente, em qualquer caso um contrato preliminar ou preparatório do negócio definitivo, contrato de segurança ou de garantia do negócio prometido:

O contrato-promessa situa-se entre a fase pré-contratual e o contrato definitivo. Há contrato-promessa apenas quando os contraentes tenham querido obrigar-se à conclusão de certo (futuro) contrato - o contrato definitivo ou contrato prometido. Logo, a distinção apresenta-se fácil: no contratompromessa, as partes obrigam-se a contratar; no contrato definitivo, as partes querem que o mesmo produza os efeitos finais, por exemplo, a transferência da propriedade ${ }^{34}$.

Em contrapartida, nas negociações preliminares, as partes estão deliberando acerca das condições do contrato a celebrar, vale dizer que sequer definido está se efetivamente chegarāo a pactuar. Para Faggella, citado por Cristina Paqual ${ }^{35}$, no período dos negócios preliminares, é possível promover a distinçāo entre dois momentos: o primeiro ocorre quando as partes discutem e trocam idéias, projetando o futuro contrato, as cláusulas, pactos e condições; e o segundo, que traduz no momento decisivo da concreta proposta e da aceitação. Ainda, para referido autor, possível se torna distinguir o período pré-contratual em três fases, de modo que tem início com a pré-formativa da oferta (na qual se verifica a presença da vontade de negociar); a fase de elaborar a proposta; e, por fim, a fase da perfeição da oferta, quando a mesma é formulada definitivamente e posta em operação para o destinatário para o aceite.

Oferta é a declaração inicial de vontade direcionada à realização de um contrato. Ainda, o legislador denomina as propostas ao público em geral de ofertas, no art. $429^{36}$ do Código Civil, acompanhando o Código de Defesa do

33 A nomenclatura é extremamente discutida. Os alemães utilizam a denominação contrato anterior, antecontrato ou pré-contrato. Os italianos utilizam contratto preliminare. No direito brasileiro, sāo as correntes de designações de pré-contrato e de contrato preliminar. ALMEIDA COSTA, Mário Júlio de. Contrato-promessa - uma síntese do regime vigente. 7a ed., rev. e actual. Coimbra, Almedina, 2001, p. 11.

34 SLLVA, João Calvão da. Sinal e contrato-promessa, 9a ed., rev. e aument., Coimbra, Almedina, 2002, p. 25.

35 FAGELLA, Gabrielle. Dei periodi precontrattuali e della lora vera ed esatta construzioni scientifica. In: Studi giuridici in onore di Carlo Fadda pel XXV anno del suo insegnamento. Napoli: Luigi Pierrô, Tip. Editore, volume terzo, 1906, p. 272, apud PASQUAL, Cristina Stringari. Estrutura e vinculação da oferta no Código de Defesa do Consumidor. Trabalho de dissertação de Mestrado, orientadora Profa. Dra. Cláudia Lima Marques, Universidade Federal do Rio Grande do Sul: Porto Alegre, 2003, p. 81.

36 Art. 429 CC. A oferta ao público equivale a proposta quando encerra os requísitos essenciais ao contrato, salvo se o contrário resultar das circunstâncias ou dos usos. Parágrafo único. Pode revogarmse a oferta pela mesma via de sua divulgação, desde que ressalvada esta faculdade na oferta realizada. 
Consumidor. No microssistema, a oferta ao público constitui negócio jurídico, eis que cria obrigações para um indivíduo, não olvidando, nesta esteira, dos negócios jurídicos unilaterais ${ }^{37}$. A Jurisprudência já absorveu o sentido de vinculação constante na oferta ao público:

Negócio jurídico e sua interpretação - obrigaçăo assumida, em oferta ao público, em típica promoção de vendas, de readquirir quotas consortis, ao valor do bem, preço do dia - Intolerável reduzir valor, pelo expurgo da atualização monetária, beneficiando-se da desdita financeira daquele que acreditou na publicidade que se oferecia como enganosa, a vingar tese da embargante (EMI 194193652, 30 Grupo Cível, TARGS, juiz Armínio José Abreu Lima da Rosa, j. 28.04.1995).

O caráter de vinculação atribuído à oferta somente poderá ser-lhe afastado se existente declaraçāo contrária nela própria ou devido à natureza do contrato ou até mesmo às circunstâncias do $\mathrm{caso}^{38}$. Segundo Carlyle Popp, as possibilidades de revogação dessa oferta são acompanhadas das declaraçōes sem compromisso ou salvo confirmação ${ }^{39}$. O caráter irrevogável da oferta tem sua explicação pela proteção à boa-fé e à confiança ${ }^{40} \mathrm{criadas}$ na outra parte contratante. Por outro lado, regulada pelo Código Civil, em seu art. 427, está a proposta ${ }^{41}$ direcionada aos comerciantes, ou seja, "obrigatória e com força vinculante em relação a quem a formula, também devendo ser mantida por certo tempo ${ }^{42 \prime \prime}$. De ressaltar que, para concluir o contrato, apresentada a proposta pelo fornecedor, é necessário o consentimento do

37 MARQUES, Cláudia Lima; BENIAMIN, Antonio Herman V.; e MIRAGEM, Bruno. Comentários ao Código de Defesa do Consumidor: arts. 10 a 74 - aspectos materiais. São Paulo: Editora Revista dos Tribunais, 2003, p. 409.

3в O ofertante vincula-se à oferta e pela oferta, até o momento em que cessam as possibilidades de aceitação por parte do consumidor, ou à conclusão. MARQUES, Cláudia Lima. Contratos no código de defesa do consumidor: o novo regime das relações contratuais. $4 \mathrm{a}$ ed., rev., atual. e anjpl. São Paulo: Editora Revista dos Tribunais, 2002 , p. 600 .

39 POPP, Carlyle. Responsabilidade civil prénegocial: o rompimento das tratativas. 1a ed., 3a tir. Curitiba: Juruá, 2003 , p. 236.

43 POPP, Carlyle. Responsabilidade civil pré-negocial: o rompimento das tratativas. 1â ed., 3a tir. Curitiba: Juruá, 2003, p. 238.

43 Art. 427 CC. A proposta de contrato obriga o proponente, se o contrário nảo resultar dos termos dela, da natureza do negócio, ou das circunstâncias do caso.

42 MARQUES, Claudia Lima; BENIAMIN, Antonio Herman V.; e MIRAGEM, Bruno. Comentários ao Código de Defesa do Consumidor: arts. 1o a 74 - aspectos materiais. Sảo Paulo: Editora Revista dos Tribunais, 2003, p. 409. 
outro parceiro contratual ${ }^{43}$, ou, como coloca Sílvio Luis Ferreira da Rocha, basta que ocorra a aceitação da oferta pelo destinatário ${ }^{44}$. Vale dizer que o proponente está, tão somente, obrigado pela proposta que apresentou, eis que sujeito passivo de um dever jurídico. Não fica obrigado a efetuar a prestação principal, tendo em vista que necessita o aceite do destinatário, a partir de quando terá nascido a obrigação principal. Imperioso ressaltar o caráter também irrevogável da proposta, de modo que deve estar o ofertante sujeito, dentro de determinado espaço de tempo, à aceitação por parte do comerciantedestinatário, enfim, de sua proposta. Cláudia Lima Marques coloca que deve o proponente observar certa conduta, de modo a manter a oferta no interesse do titular do direito subjetivo ${ }^{45}$.

O objetivo do legislador, ao controlar a publicidade veiculada pelos fornecedores - primando pela transparência na veiculação do produto, objeto de estudo na sequência - é alterar as práticas comerciais, aumentando o controle sobre a chamada publicidade-chamari ${ }^{46}$, uma prática, de certa forma, consolidada no mercado brasileiro. A Jurisprudência brasileira tem demonstrado que de enorme relevância o controle efetuado sobre a publicidade:

Direito do consumidor - Lei 8.078/90 e Lei 7.565/86 relação de consumo - incidência da primeira - serviço de entrega rápida - entrega não efetuada no prazo contratado dano material - indenização não tarifada. I - Não prevalecem as disposições do Código Brasileiro de Aeronáutica que conflitem com o Código de Defesa do Consumidor. 11 - As disposições do Código de Defesa do Consumidor incidem sobre a generalidade das relaçōes de consumo, inclusive as integradas por empresas aéreas. III - Quando o fornecedor faz constar de oferta ou mensagem publicitária a notável pontualidade e eficiência de seus serviços de entrega, assume os eventuais riscos de sua atividade, inclusive o chamado risco aéreo, com cuja conseqüência não deve arcar o consumidor.

43 MARQUES, Cláudia Lima; BENIAMIN, Antonio Herman V.; e MIRAGEM, Bruno. Comentários ao Código de Defesa do Consumidor: arts. 10 a $\mathbf{7 4}$ - aspectos materiais. São Paulo: Editora Revista dos Tribunais, 2003, p. 409.

4 ROCHA, Sílvio Luis Ferreira da. Efro na oferta no Código de Defesa do Consumidor. In: Revista de Direito do Consumidor, 09, p. 58-62.

45 MARQUES, Clâudia lima. Contratos no código de defesa do consumidor: o novo regime das relações contratuais. $4 \mathrm{a}$ ed., rev, atual. e ampl. São Paulo: Editora Revista dos Tribunais, 2002, p. 601.

46 Oferta na qual o fornecedor apresenta produto a preço vantajoso, mas, quando comparece o consumidor na loja, é informado de que os poucos exemplares à preço baixo já foram vendidos. In: MARQUES, Cláudia Lima; BENIAMIN, Antonio Herman $V_{\text {; }}$ e MIRAGEM, Bruno. Comentários ao Código de Defesa do Consumidor: arts. to a 74 - aspectos materiais. Sảo Paulo: Editora Revista dos Tribunais, 2003, p. 410. 
IV - Recurso especial não conhecido (ST) - $3^{\mathrm{a}} \mathrm{T}$. - Resp. 196031/MG - rel. Min. Antônio de Pádua Ribeiro - j. 24.04.2001).

\section{B) A transparência e o dever de informar.}

O princípio da transparência, segundo Cláudia Lima Marques, rege o momento pré-contratual, a eventual conclusão do contrato. Mais do que simples elemento formal, "ele afeta a essência do negócio, eis que a informação que repassa integra o conteúdo do contrato, ou, se falha, representa a falha na qualidade do produto ou serviço oferecido ${ }^{47 "}$. Tal princípio concretiza a idéia de reequilíbrio de forças nas relações de consumo, em especial na conclusão de contratos de consumo - impostos pelo CDC como forma de alcançar a almejada justiça contratual.

Como reflexo do princípio da transparência, há o novo dever de informar o consumidor, seja através da oferta ${ }^{48}$, ou através do próprio texto do contrato ${ }^{49}$. A transparência jurídica busca assegurar que o consumidor possa manifestar e formar livremente sua vontade negocial, de modo que tenha conhecimento de seus direitos e deveres referentes ao futuro contrato. Mas a transparência jurídica serve também para a realização melhor ou perfeita da obrigação, pois a falta de transparência impede, muitas vezes, que o consumidor saiba os seus direitos pelo contrato ou facilita que o fornecedor demande deveres não existentes para o consumidor. De acordo com a doutrina de Alcides Tomasetti Jr., transparência significa:

Uma situação informativa favorável à apreensão racional pelos agentes econômicos que figuram como sujeitos naquelas declarações (negociais para consumo) e decorrentes nexos normativos - dos sentimentos, impulsos e interesses, fatores, conveniências e injunções, todos os quais surgem ou são suscitados para interferir e condicionar as expectativas e

47 MARQUES, Cláudia Lima. Contratos no código de defesa do consumidor: o novo regime das relaçốes contratuais. $4 a$ ed., rev., atual. e ampl. Sạo Paulo: Editora Revista dos Tribunais, 2002, p. 598.

48 "Quando trata da oferta, o CDC prevê que esta séja clara e correta -. leia-se publicidade ou qualquer outra informaçâo suficiente --.- art. 30 , sobre as qualidades do produto e as condiçóes do contrato, sob pena de o fornecedor responder pelas fathas na informação ou ser obrigado a cumprir a oferta nos termos em que foi feita". MARQUES, Cláudia Lima. Contratos no código de defesa do consumidor: o novo regime das relações contratuais. 4a ed., rev., atual, e ampl. Säo Paulo: Editora Revista dos Tribunais, 2002, p. 599. unilateralmente, devendo o fornecedor dar oportunidade ao consumidor, conhecer o conteúdo das obrigações que assume, sob pena do contrato por decisão judicial não obrigar o consumidor, mesmo se devidamente formalizado". MARQUES, Cláudia Lima. Contratos no código de defesa do consumidor: o novo regime das relações contratuais. 4a ed., rev., atual. e ampl. Săo Paulo: Editora Revista dos Tribunais, 2002, p. 599. 
comportamentos daqueles mesmos sujeitos, enquanto consumidores e fornecedores conscientes de seus papéis, poderes, deveres e responsabilidades ${ }^{50}$.

Uma concretização tópica da transparência jurídica está nos arts. 30 e 31 do Código de Defesa do Consumidor, significando clareza como um dever obrigacional, relativamente às ofertas existentes no mercado econômico ${ }^{51}$. Cristoph Fabian coloca que a transparência, nesse contexto, "assegura que o consumidor se informe rapidamente e de forma segura sobre as ofertas dos vários concorrentes no mercado ${ }^{52 "}$. O acesso à informação é indeclinável para que o consumidor possa exercer dignamente o direito de escolha, principalmente quando as necessidades são induzidas pela publicidade massificada ${ }^{53}$. Aí entra o conceito, de imensa importância, previsto no Código de Defesa do Consumidor, referente ao princípio da transparência:

Art. 30. Toda informação ou publicidade, suficientemente precisa, veiculada por qualquer forma ou meio de comunicação com relação a produtos e serviços oferecidos ou apresentados, obriga o fornecedor que a fizer veicular ou dela se utilizar e integra o contrato que vier a ser celebrado.

Art. 31. A oferta e apresentação de produtos ou serviços devem assegurar informações corretas, claras precisas, ostensivas e em língua portuguesa sobre suas características, qualidades, quantidade, composição, preço, garantia, prazos de validade e origem, entre outros dados, bem como sobre os riscos que apresentam à saúde e segurança dos consumidores. (grifo nosso)

O Prof. Antônio Herrman de Vasconcellos e Benjamin, nos Comentários ao Código de Defesa do Consumidor, trata do dever de informar por parte do fornecedor como reconhecimento de que o consumidor tem direito de informação sobre os produtos e serviços que pretende adquirir. Reconhece, portanto, que na sociedade de consumo está sempre o consumidor mal informado, desconhecendo a real qualidade do bem ofertado, de modo que incapaz de fazer uma escolha livre:

\footnotetext{
so TOMASETTI IR., Alcides. O objetivo de transparência e o regime jufídico dos deveres e riscos ifformação nas declarações negociais para consumo. In: Revista de Direito do Consumidor, 04, p. 53.

5) FABIAN, Cristoph. O dever de informar no direito civil. São Paulo: Editora Revista dos Tribunais, 2002, p. 69.

32 FABIAN, Cristoph. O dever de informar no direito civil. São Paulo: Editora Revista dos Tribunais, 2002, p. 69 .

5â LOOBO, Paulo Luiz Netto. A informação como direito fundamental do consumidor. In: Revista de Direito do Consumidor, 37 , p. 61 .
} 
Como consequiência, o Estado intervém para assegurar, em face da falha de funcionamento do mercado, que os consumidores recebam informações adequadas que os habilitem a exercer, de maneira consciente e livre, suas opções de consumo. ${ }^{54}$

Adalberto Pasqualotto ressalta que está diretamente ligado à transparência da informação o princípio da veracidade da publicidade, mesmo considerando a contraposiçäo de interesses, eis que a primeira é um dever dos fornecedores, e a publicidade é o objeto atrativo para os consumidores, e mesmo que não seja enganosa, é naturalmente tendenciosa ${ }^{55}$. E complementa que somente são passíveis de comprovação os dados fatuais referidos na mensagem publicitária que digam respeito a elementos, tais como características, qualidade, quantidade, composição, preço, garantia, prazo de validade, origem, etc., todos relevantes o suficiente para formar a persuasão relativamente ao produto anunciado $^{56}$. De relembrar que transparência também significa redação clara e em linguagem compreensível e inteligível das cláusulas contratuais ${ }^{57}$.

Segundo o princípio da transparência, o consumidor deve possuir informações precisas e claras sobre os produtos e serviços existentes no mercado, de modo a ver o princípio vinculado a um dos principais postulados da economia clássica, qual seja, o de que o funcionamento eficiente do mercado depende das informações que os agentes econômicos dispuseram sobre os bens trocados. De ressaltar o art. $6^{\circ}$ do $\mathrm{CDC}^{58}$, que tem em seu bojo o direito à informação por parte do consumidor no momento, não limitado este à fase pré-contratual. Assim coloca Alberto do Amaral Jr.:

O direito à informação nāo se limita à fase pré-contratual, abrangendo o conteúdo das relaçōes contratuais. Os contratos para o consumo devem ser redigidos de forma clara sob pena de não vincularem os consumidores ${ }^{59}$.

54 GRINOVER, Ada Pelegrini (et. al.). Código brasileiro de defesa do consumidor comentado pelos autores do anteprojeto. $7 \mathrm{a}$ ed. Rio de Janeiro: Forense Universitária, 2001, p. 245.

35 PASQUALOTTO, Adalberto de SOuza. O regime obrigacional da publicidade nas relaçöes de consumo. Trabalho de dissertaçào de Mestrado, orientador Dr. Nelson Nery Júnior, Universidade Federal do Rio Grande do Sul: Porto Alegre, 1995, p. 99.

56 PASQUALOTTO, Adalberto de Souza. O regime obrigacional da publicidade nas relaçöes de consumo. Trabalho de dissertaçăo de Mestrado, orientador Dr. Nelson Nery Júnior, Universidade Federal do Rio Grande do Sul: Porto Alegre, 1995, p. 100.

57 MARQUES, Cláudia Lima. Contratos no código de defesa do consumidor: o novo regime das relaçôes contratuais. 4a ed., rev, atual. e ampl. São Paulo: Editora Revista dos Tribunais, 2002, p. 595.

58 "Art. 60 CDC. São direitos básicos do consumidor:(...) 1111 - a informaçăo adequada e clara sobre os diferentes produtos e serviços, com especificação correta de quantidade, características, composição, qualidade e preço, bem como sobre os riscos que apresentem."

s. AMARAL. JR., Alberto. O princípio da vinculaçăo da mensagem publicitária. In: Revista de Direito do Consumidor, 14, p. 46. 
A vulnerabilidade do consumidor manifesta-se acentuadamente em matéria de publicidade, de modo que os consumidores se acham tão expostos às campanhas publicitárias, que procuram criar necessidades e estimular a demanda. Nesse contexto, referido autor conclui que "a ausência da força vinculante da mensagem publicitária comportaria a possibilidade da prática de incontáveis abusos ${ }^{60}$ ". Não raro surgem as práticas abusivas, de modo que danos daí também surgem, a ponto da publicidade, ao ser veiculada, ver impostos deveres éticos de lealdade e transparência, com o intuito de proibir atos ilícitos, o que nem sempre é possível.

Consumidor. Publicidade enganosa. Obrigação de adimplir com a obrigação. 1. Fundada a demanda em publicidade enganosa (art. 37, par. 10, da Lei 8078/90), responde perante o consumidor quem promoveu tal publicidade, no caso de a empresa que administra e gerencia empreendimentos lotéricos. Preliminar de ilegitimidade passiva rejeitada. 2. Tendo a Ré, promotora de jogos, se obrigado, através de publicidade, sob a forma de release, posteriormente divulgado no jornal "Zero Hora", a entregar um automóvel a quem completasse o bingo em primeiro lugar, não pode se furtar ao adimplemento da obrigação perante o ganhador, a teor dos artigos $35, \mathrm{l}$, par. $1^{\circ}$. e 37 , par. $1^{\circ}$ e par. $3^{\circ}$. da Lei $n^{\circ}$. $8078 / 90$, pretextando que, no dia, houve o anúncio de uma rodada especial. 3. Apelação desprovida. (Apelação Cível n. 596116764, Quinta Câmara Cível, Tribunal de Justiça do RS, Relator: Araken de Assis, Julgado em 14/11/1996).

Segundo Antônio Herrman Benjamin, "publicidade é toda a informação dirigida ao público com o objetivo de promover, direta ou indiretamente, uma atividade economica ${ }^{61 "}$. Considerada como "o conjunto de processos técnicos destinados a atrair a atenção do público, informando-o sobre um produto, um serviço ou uma ação ${ }^{62 "}$, tem como escopo o convencimento do auditório para que compre, utilize ou participe do material veiculado. Vera Fradera coloca que a publicidade é fenômeno que faz parte do dia-a-dia das pessoas, desde o início da vida:

6 AMARAL JR., Alberto. O princípio da vinculação da mensagem publicitária. In: Revista de Direito do Consumidor, 14, p. 46.

61 GRINOVER, Ada Pelegrini (et. al.). Código brasileiro de defesa do consumidor comentado pelos autores do anteprojeto. 7a ed. Rio de Janeiro: Forense Universitária, 200, p. 170 e ss.

62 FRADERA, Vera Maria Jacob de. A interpretação da proibiçâa de publicidade enganosa ou abusivà à luz do principio da boa-fé: o dever de informar no Código de Defesa do Consumidor. In: Revista de Direito do Consumidor, 04, p. 181. 
É através dela que o Mundo, em todas as suas facetas, nos é oferecido, como se fora uma vitrine, onde são expostas as "novidades" que, a partir de então, passam a ser "necessidades", mostradas que são como indispensáveis ao conforto e à atualização da vida e dos lares ${ }^{63}$.

Através do meio de difusão - elemento material da publicidade, seu meio de expressão - e da informação - seu elemento finalístico - será atingido o consumidor, alvo principal do anunciante ${ }^{64}$. O Código de Defesa do Consumidor introduziu diversos novos devere ${ }^{65}$ no ordenamento brasileiro para o fornecedor que utiliza a publicidade ${ }^{66}$ no mercado, como método de incitação ao consumo, sendo que o principal deles é o da veracidade especial. A partir do momento em que comunica, portanto, é meio de informação, deve, assim, ser a informação verdadeira:

Art. 36. A publicidade deve ser veiculada de tal forma que o consumidor, fácil e imediatamente, a identifique como tal.

Parágrafo único. O fornecedor, na publicidade de seus produtos ou serviços, manterá, em seu poder, para informação dos legítimos interessados, os dados fáticos, técnicos e científicos que dão sustentação à mensagem.

No Código de Defesa do Consumidor, a prática comercial publicidade é verdadeira atividade social de cooperação, ato juridicamente relevante, mencionado em três momentos distintos: quando suficientemente precisa, é classificada ora como parte da oferta, vinculando o negócio jurídico unilateral como a proposta (art. 30) ${ }^{67}$; quando abusiva ou enganosa, é proibida ou

63 FRADERA, Vera Maria jacob de. A interpretaçảo da proibiçāo de publicidade enganosa ou abusiva à luz do princípio da boa-fé: o dever de informar no Código de Defesa do Consumidor. In: Revista de Direito do Consumider, 04, p. 181.

64 GRINOVER, Ada Pelegrini (et, al.). Código brasileiro de defesa do consumidor comentado pelos autores do anteprojeto. $7^{\circ}$ ed. Rio de Janeiro: Forense Universitária, 2000, p. 170 e 55.

65 "Tendo em vista o fabricante ou fornecedor, enfim, o que coloca o produto no mercado, é ele live de optar por qualquer uma das formas de publicidade. No momento em que decide fazê.lo, está sujeito a uma série de normas que regulam cogentemente seu comportamento na difusăo do produto, tendo em vista a proteçăo do destinatário da mensagem publicitária, considerado parte vutnerável na relação de consumo, e a manutenção do equifibrio entre as partes". FRADERA, Vera Maria lacob de. A interpretaçảo da proibição de publicidade enganosa ou abusiva à fuz do principio da boa-fé o dever de informar no Código de Defesa do Consumidor. In: Revista de Direito do Consumidor, 04, p. 182.

66 Valeria Claise diferencia bem publicidade de propaganda, de modo que classifica propaganda como o meio através do qual se busca influenciar ou modificar a opiniăo alheia a respeito de determinada ideologia; publicidade visa, para a autora, captat a atença do público para o consumo de deteminados bens ou pata a utilização de certos serviços, porém sempre corn fins comerciais. CHAISE, Valéria Falcào. A publicidade como causa de obrigação. Trabalho de dissertaçăo de Mestrado, orientador Dr. Luis O. Andorno, Universidade Federal do Rio Grande do Sul: Porto Alegre, 1998, p. 20.

67 Art. 30 CDC. Toda informação ou publicidade, suficientemente precisa, veiculada por qualquer foma ou meio de comunicaçäo, com relação a produtos e serviços oferecidos ou apresentados, vincula o fornecedor que a fizer veicular ou dela se utilizar e integra o contrato que vier a ser celebrado. 
sancionada (art. 37) ${ }^{68}$, constituindo ato ilícito violador de direitos; e nos demais casos, como prática comercial correta, leal (art. $6^{\circ}, \mathrm{IV}$ ), nas informações que presta (art. 36, parág. único) e despida de valoração negativa pela eventual ilicitude (art. 36, caput) ${ }^{6970}$.

A partir das expectativas legítimas criadas pelos fornecedores no outro contratante, ou seja, na população atingida pela declaração enganosa e, conseqüentemente, na confiança despertada no homem médio, muitas vezes, "pela simples atividade de publicidade como determinação soberana e profissional do fornecedor e sob o risco profissional deste ${ }^{71 "}$, em ocorrendo qualquer falha ou erro, deveres de indenizar dos riscos da publicidade são derivados, e serão examinados na segunda parte.

\section{II - A RUPTURA DAS NEGOCIAÇÕES PRELIMINARES PELA PUBLICIDADE.}

De imensa importância ressaltar aqui a noçāo de obrigação como processo, desenvolvida na Alemanha nas décadas de 50-60 e no Brasil introduzida por Clóvis do Couto e Silva ${ }^{72}$, desde que, no caso em tela, ao conceber uma visão dinâmica e total da obrigação, como um conjunto de deveres que vinculam as partes desde a aproximação negocial (momento précontratual) até mesmo depois de cumprido o dever principal (pós-eficácia dos contratos). Foi a publicidade valorizada como ato de vontade inidôneo para criar vínculos obrigacionais (com ou sem contrato) entre fornecedores e consumidores na sociedade brasileira. $E$ daí surge a questão: teria a publicidade veiculada passado a formar para o fornecedor responsável algum dever jurídico? Seria a publicidade ${ }^{73}$ nova fonte de deveres anexos ${ }^{74}$ ? De ressaltar que a jurisprudência tem respondido à questão em tom uníssono:

6r Art. 37 CDC. E proibida toda a publicidade enganosa ou abusiva. (...)

69 Art. $6^{\circ} \mathrm{CDC}$. Săo direitos básicos do consumidor: (...) Ill - a informaçăo adequada e clara sobre os diferentes produtos e serviços, com especificaçăo correta de quantidade, características, composiçăo, qualidade e preço, bem como sobre os riscos que apresentem.

70 MARQUES, Cláudia Lima. Vinculação própria através da publicidade? A nova visão do Código de Defesa do Consumidor. In: Revista de Direito do Consumidor, 10, p. 12.

7: MARQUES, Cláudia Lima. Vinculação própria através da publicidade? A nova visăo do Código de Defesa do Consumidor. In: Revista de Direito do Consumidor, 10, p. 18.

72 SILVA, Clóvis Veríssimo do Couto e. A obrigaçăo como processo. Sảo Paulo: José Bushatsky, 1976, p. 100.

73 Em estudo apresentado na Revista de Direito do Consumidor, Vera Fradera coloca claramente que "o dever de informar é classificado como dever anexo". FRADERA, Vera Maria lacob de. A interpretaçāo da proibição de publicidade enganosa ou abusiva à luz do principio da boa-fé: o dever de informar no Código de Defesa do Consumidor. In: Revista de Direito do Consumidor, 04, p. 174.

7. Considerando a nova concepção de que credor e devedor não representam mais partes antagônicas da relaçäo jurídica, e que devem, portanto, agir em cooperação um para com o outro, foi desenvolvida pela doutrina a idéia dos deveres anexos, passando a ser vista a obrigação como um todo. SILVA, Clóvis Veríssimo do Couto e. A obrigação como processo. Săo Paulo: José Bushatsky, 1976, p. 08. 
Ementa: Civil. Seguro-saúde. Cláusula de exclusāo. Inespecificidade. Iniqüidade e abusividade. Código Civil e do Consumidor. Aplicação aos contratos em andamento. A exclusão das consequêencias das doenças crônicas da cobertura do contrato praticamente deixou a segurada, pessoa sem grandes conhecimentos, fora de qualquer cobertura, tendo em vista a sua abrangência inespecífica. Por igual, a ausência de explicação conceitual ao nível do homo medius, do verdadeiro significado de doença crônica, também conduz a iniqüidade da cláusula e a torna abusiva. Não se compreende que num contrato como o que assinam os segurados da Golden Cross, não são esclarecidos estes pontos importantes que dizem respeito à abrangência das exclusões de cobertura. A inespecificidade e a falta de conceito tornam a cláusula passível de anulabilidade, a teor do art. 115 do Código Civil. Tal dispositivo encontra redação mais clara e moderna no art. 51, inc. IV, do Código de Defesa do Consumidor, mas ambos buscam praticamente o mesmo escopo, que é o de proteger uma das partes da relação contratual contra o arbítrio da outra. Apelo provido. (Apelação Cível no. 598427227, Quinta Câmara Cível, Tribunal de Justiça do RS, Relator: Carlos Alberto Bencke, Julgado em 08/04/1999).

\section{A) A culpa in contrahendo e os novos tipos de vinculação sem contrato.}

A teoria da culpa in contrahendo veio à luz em 1861, por Rudolf Von Jhering, consistindo em estudo realizado acerca de situações de injustiça, originadas na não-imputação de responsabilidade por danos e custos, derivados de contratos nulos ${ }^{75}$. A preocupação de Jhering consistia no alcance da teoria da vontade, dominante naquele momento, e segundo a qual a vontade interna, psicológica, seria o elemento fundamental do negócio jurídico e, uma vez flagrante a divergência entre a declaração do contratante e sua real intenção, deveria prevalecer a segunda. Com base na confiança da parte prejudicada na validade do negócio jurídico, acaba Jhering concluindo pela possibilidade de reparação pecuniária do interesse prejudicado pela declaração de invalidade do negócio firmado.

Karl Larenz coloca que a maior ampliação da responsabilidade originada pela confiança entre as partes teria sua origem na conexão com os deveres de proteção, precedentes do princípio da boa-fé, que acabou por constituir modo

75 MENEZES CORDEIRO, António Manuel da Rocha e. Da boa-fé no direito civil. Coimbra: Almedina, 2001, p. 529. 
de desenvolvimento do Direito superador da lei, em busca de maior eqüidade entre as partes ${ }^{76}$. E assim afirma:

Aquele que mantém negociações contratuais com outrem aceita já, por via disso, deveres acrescidos, não só os relativos à omissão de actos lesivos, mas também os relativos a um agir positivo, sempre que a outra parte possa, segundo as circunstâncias, esperar isso de si. ${ }^{77}$

Desde o início dos estudos em torno da teoria da culpa in contrahendo, dúvidas surgiram acerca da sua natureza, de sua origem, de modo que, geralmente, tem sido aceita sua estreita ligação ao princípio da boa-fé e aos deveres de proteção dele procedentes, de modo a permear todo o ordenamento jurídico ${ }^{78}$. Os pontos finais da teoria da culpa in contrahendo de Jhering foram colocados da seguinte forma:

a) A culpa in contrahendo é de natureza contratual, que se revela no momento da formação do contrato ${ }^{79}$;

b) O mesmo grau de diligência deve ser prestado no período de formação e execução do contrato;

c) Somente os contratantes podem incidir nessa espécie de culpa, estando excluídos os terceiros;

d) Se o ato pretendido não é contrato, resta excluída a culpa in contrahendo;

e) Para que possa ter havido culpa, é necessária a oferta - não bastando as tratativas, o que foi, de pronto, rebatido por Gabrielle Fagella, que trouxe ao estudo da responsabilidade pré-contratual a etapa das tratativas preliminares (anteriormente estudada), eis que sustenta o fundamento da responsabilidade como a violação do acordo concluído expressa ou tacitamente para estabelecer negociações, e não na culpa, como thering ${ }^{80}$. (grifo nosso)

76 LARENZ, Karl. Metodología da Ciência do Direito. $3^{2}$ ed., Lisboa: Fundação Calouste Gulbenkian, p. 600.

77 LARENZ, Karl. Metodologia da Ciência do Direito. $3^{3}$ ed. Lisboa: Fundaçăo Calouste Gulbenkian, p. 602.

78 SILVA, Almiro do Couto e. Responsabilidade pré-negocial e culpa in contrahendo no Direito Administrativo Brasifeiro. In: Revista Brasileira de Direito Comparado, Rio de Janeiro, n. 18, 2000, p. 206.

79 Menezes Cordeiro cita Leonhard, F., que brilhantemente conclui por ser o dever de cuidado de natureza contratual, eis que "näo seria certo derivar una responsabilidade de meras negociações que não conduzam ao alvo". LEONHARD, F. Verschulden beim Vertragsschlusse, 1910, p. 58, apud MENEZES CORDEIRO, António Manuel da Rocha e. Da boa-fé no direito civil. Coimbra: Almedina, 2001, p. 535.

80 CHAISE, Valéria Falcăo. A publicidade como causa de obrigação. Trabaho de dissertação de Mestrado, orientador Dr. Luis O. Andorno, Universidade Federal do Rio Grande do Sul: Porto Alegre, 1998, p. 57. 
Muito embora tenha concluído o autor que da nulidade de um contrato poderiam ainda emergir alguns efeitos, seu escopo fundamental é o cumprimento, de modo que os acessórios - como a restituição da coisa, sinal ou indenização - também restam flagrantes. Para Jhering, portanto, a culpa in contrahendo é um instituto da responsabilidade civil, pelo qual, havendo nulidade no contrato, uma das partes, que tenha ou devesse ter conhecimento do óbice, deve indenizar a outra pelo interesse contratual negativo. Originada nos conceitos da culpa in contrahendo, acaba nascendo o que os alemães chamam de teoria da confiança ${ }^{81}$, de modo que, segundo Menezes Cordeiro, as partes assumiriam, no início das negociações, um dever correto de conduta ${ }^{82}$, um dever de cuidado para com a outra parte.

Dentre eles, é de ser citado o manifesto de Pontes de Miranda, ao colocar a in contrahendo como toda infração de dever de atenção que se há de esperar de quem vai concluir contrato, de modo que foi tal dever criado pelos usos do tráfico, podendo ser o "dever da verdade, da diligência no exame do objeto, exatidão no modo de exprimir-se, quer em punctuações, anúncios, minutas ou informes ${ }^{83 "}$.

Com o passar dos anos, de enorme importância a tese desenvolvida por Köendgen para o Direito do Consumidor, que aborda a identificação de novos vínculos jurídicos que não somente os contratos, vinculaçōes estas surgidas entre indivíduos em virtude de riscos profissionais de cada um, da confiança criada por determinada atividade que necessite de contato social mais especializado com fim (direto ou indireto) de lucro ${ }^{84}$. Para bem identificar o tema, restringiu-o à vinculação dinâmica, por atuação de vontade na sociedade, e afirma que a determinação juridicamente relevante é a "determinação própria" (Selbstbestimmung), razão pela qual propōe estudar a "vinculação própria" (Selbsbindunng), que seria a alma, a essência das obrigações no mundo individualista, capitalista e liberal, pós-Revolução Francesa.

O jurista procura defender em sua tese a responsabilidade por atos com finalidade (direta ou indireta) negocial, denominados "quase-contratos", com

s1 SILVA, Almiro do Couto e. Responsabilidade pré-negocial e culpa in contrahendo no Direito Administrativo Brasileiro. In: Revista Brasileira de Direito Comparado, Rio de Janeiro, n. 18, 2000, p. 206.

82 MENEZES CORDEIRO, António Manuel da Rocha e. Da boa-fé no direito civil. Coimbra: Almedina, 2007 , p. 529 .

83 MIRANDA, Pontes de. Tratado de Direito Privado. $4^{*}$ ed. São Paulo: Revista dos Tribunais: 1984. T. 38, p. 321.

a4 KÖENDGEN, Johannes. Sebstbindung ohne Vertrag - Zur Haftung aus geschäftsbezogenem Handeh. Tubingen: J.C. B. Mohr, 1981, p. 284, apud MARQUES, Cláudia Lima. Vincutação própria através da publicidade? A nova visáo do Código de Defesa do Consumidor. In: Revista de Direito do Consumidor, 10, p. 16. 
projeção necessária da obrigação ou vinculação própria ${ }^{85}$. Köendgen muito discutiu a responsabilidade nos casos em que ocorria a vinculação sem contrato, o que defendeu ora pela confiança (Vertrauenshaftung) existente entre as partes; ora pela atividade dirigida e profissional do fornecedor; e, finalmente, pela confiança que representa o efeito provável daquele tipo de declaração na sociedade (também standard objetivo).

Dos estudos de Köendgen, é de concluir que a atividade da publicidade é opção do fornecedor (livre determinação), mas que por suas características de atividade profissional (risco próprio) e por seus importantes e irreversíveis efeitos na sociedade efeitos na sociedade (confiança despertada) faz nascer vínculos obrigacionais, tornando-se de relevância jurídica indiscutível. ${ }^{86}$ (grifo nosso)

De mencionar alguns exemplos de decisões jurisprudências que seguiram os estudos acerca da vinculação sem contrato.

Civil e processual - promessa de compra e venda - imóvel - inscrição no registro imobiliário - adjudicação - outorga uxória - precedentes da corte. 1 - A promessa de compra e venda gera efeitos obrigacionais não dependendo, para sua eficácia e validade, de ser formalizada em instrumento público. O direito a adjudicação compulsória é de caráter pessoal, restrito aos contratantes, não se condicionando a obligatio faciendi à inscrição no registro de imóveis. (Resp. 247.344/ MG, j. 19.02.2001, Waldemar Zveiter).

Direitos do consumidor - fornecedor - responsabilidade em contrato de empreitada - oferta e publicidade. Se o fornecedor de casa pré-fabricada permite a inserção de seu nome em oferta e propaganda de empreiteira, torna-se responsável pela obra não realizada pela última. Inteligência do art. 30 e seguintes do CDC. Apelação improvida (T)RS $10^{2}$ Câm. - ApCiv 70001658228 - rel. Des. Luiz Ary Vessini de Lima - j. 12.04.2001).

Propriedade industrial - marca nominativa - nome de hospital - uso da mesma expressão em nome comercial de sociedade geriátrica - antecipação de tutela no sentido da

8: KÖENDGEN, Johannes. Sebstbindung ohne Vertrag - Zur Haftung aus geschäftsbezogenem Handeln. Tübingen: 1.C. B. Mohł, 1981, p. 284, apud MARQUES, Cláudia Lima. Vinculaçăo própria através da publicidade? A nova visão do Código de Defesa do Consumidor. In: Revista de Direito do Consumidor, 10 , p. 13.

36 MARQUES, Cláudia Lima. Vinculaçăo própria através da publicidade? A nova visão do Código de Defesa do Consumidor. In: Revista de Direito do Consumidor, 10, p. 17. 
abstenção - agravo de instrumento. A geriatria é um ramo da medicina que se ocupa com as doenças dos idosos. Assim, quando uma sociedade comercial, em seu nome, usa o vocábulo geriátrico, sucedido de uma expressão idêntica ao nome de um hospital, em princípio induz, perante o público, que a sociedade comercial é uma entidade ligada ao hospital, porquanto se ocupa com atividade afim. Agravo desprovido. (TJRS $-5^{2} \mathrm{Cam}$. - Agln 598023299 - rel. Des. Irineu Mariani - j. 26.03.1998).

São invocados os deveres de lealdade e transparência principalmente para as relações contratuais de fato, assentes em puras atuações, que consistem nas relações jurídicas que prescindem de vontade declarada pelo agente, muito embora seus efeitos jurídicos se assemelhem aos dos contratos. Köendgen coloca que a informaçäo veiculada cria uma expectativa de qualidade, que será incluída no contrato, quando o fizerem as partes ${ }^{87}$. Vale dizer que a publicidade passa a ser vista como fonte de obrigações civis, tendo como base a teoria da culpa in contrahendo, de modo que nasceria para ambas as partes um dever de cuidado, de esclarecimento e de evitar qualquer dano ao interesse da outra parte.

Entretanto, quando o contrato não for concluído pela ruptura das tratativas ou negociações preliminares, é de ser pleiteada indenização por ato ilícito, alegando comportamento desleal ou abusivo, de modo a recorrer, muitas vezes, à teoria de Jhering sobre a culpa in contrahendo. Em ocorrendo o descumprimento desses deveres pré-contratuais, o comerciante ficaria obrigado a ressarcir os danos, segundo o princípio do ressarcimento contratual, isto é, através das perdas e danos, principalmente se fosse veiculada qualquer publicidade enganosa ${ }^{88}$, o que será objeto da análise a seguir.

37 MARQUES, Cláudia Lima. Contratos no código de defesa do consumidor: o novo regime das relações contratuais. $4^{a}$ ed., rev., atual. e ampl. São Paulo: Editora Revista dos Tribunais, 2002, p. 636.

ấ $\mathrm{O}$ art. 45 do CDC tratava da sanção à publicidade enganosa, prevendo perdas e danos, a indenização por danos morais e também a imposiçăo de danos punitivos, o que acabou sendo objeto de veto do Presidente da República. Inobstante, nos arts. 186 e 187 do CC c/c o art. 927 do CC, encontra o consumidor guarida para qualquer pedido de ressarcimento com caráter punitivo, eis que expressamente mencionam o dano moral, o abuso de direito, os bons costumes e a boa-fé, frente aos prejuizos sofridos pela publicidade enganosa:

Art. $186 \mathrm{CC}$. Aquele que, por ação ou omissão voluntária, negligência ou imptudência, violar direito e causar dano a outrem, ainda que exclusivamente motal, comete ato ilicito".

Art. $187 \mathrm{CC}$. Também comete ato ilicito o titular de um direito que, ao exercê-lo, excede manifestamente os limites impostos pelo seu fim econômico ou social, pela boa-té ou pelos bons costumes.

Art. 927 CC. Aquele que, por ato ilicito (arts. 186 e 187) causar dano a outrem, fica obrigado a reparáto. Parágrafo único. Haverá obrigaçăo de reparar o dano, independentemente de culpa, nos casos específicos em lei, ou quando a atividade normalmente desenvolvida pelo autor do dano implicar, por sua natureza, risco para os direitos de outrem. 
Contrato. Compra e venda. Apartamento. Oferta. Propaganda. A promessa, constante da propaganda, de que o prédio teria telefone em todos os apartamentos, significou que a incorporadora assumia a obrigação de instalar as respectivas linhas e transferi-las aos condôminos, com os equipamentos necessários. (Apelação cível $n^{\circ} .591016530$, Quinta Câmara Cível, Tribunal de Justiça do RS, Relator Ruy Rosado de Aguiar Jr., Julgado em 06/06/1991).

\section{B) A responsabilidade pela confiança despertada.}

No tocante à publicidade como oferta contratual, vale dizer que se refere às informações suficientemente precisas, conforme Cláudia Lima Marques coloca: "estas, porém, são vinculantes e obrigam desde já o fornecedor e integram o futuro contrato $^{89 "}$. Essa obrigação possui natureza pré-contratual, pois é somente declaração unilateral de vontade da qual decorrem deveres jurídicos para o fornecedor, e à qual correspondem direitos para os consumidores expostos à publicidade. Köendgen concluiu que a vinculação própria por uso (ato ilícito) da publicidade na sociedade de $\operatorname{massas}^{90}$, ao imputar a responsabilidade pela atuação (determinação própria), atuação de risco profissional (mesmo que risco menor) com fim de lucro (direto ou indireto), que afirma que a responsabilidade pela confiança tem sua origem na responsabilidade pela participação no meio jurídico negocial ${ }^{91}$.

Ocorre que, aceita a proposta, o conteúdo da publicidade passará a integrar o contrato firmado com o consumidor, como se fosse cláusula extra, não-escrita, mas cujo cumprimento poderá ser exigido, mesmo perante o Judiciário. $O$ art. 35 do Código de Defesa do Consumidor prevê a responsabilização do fornecedor, frente à alteração da oferta veiculada:

Art. 35. Se o fornecedor do produto ou serviços recusar cumprimento à oferta, apresentação ou publicidade, o consumidor poderá, alternativamente e à sua livre escolha:

1 - exigir o cumprimento forçado da obrigação, nos termos da oferta, apresentação ou publicidade;

II - aceitar outro produto ou prestaçāo de serviço equivalente;

\footnotetext{
89 MARQUES, Cláudia Lima. Vinculaçāo própria através da publicidade? A nova visāo do Código de Defesa do Consumidor. In: Revista de Direito do Consumidor, 10, p. 13.

$9 \%$ "...fulcrada na responsabilidade pela confiança, segundo conceito desenvolvido por Canaris a respeito da confiança despertada". MARQUES, Cláudia lima. Contratos no código de defesa do consumidor: o novo regime das relaçōes contratuais. $4^{a}$ ed., rev, atual. e ampl. Săo Paulo: Editora Revista dos Tribunais, 2002, p. 609.

91 MARQUES, Cláudia Lima. Contratos no código de defesa do consumidor: o novo regime das relações contratuais. $4^{n}$ ed., rev., atual. e ampl. Săo Páulo: Editora Revista dos Tribunais, 2002, p. 609.
} 
III - rescindir o contrato, com direito à restituição de quantia eventualmente antecipada, monetariamente atualizada, e a perdas e danos.

A utilização indireta pelo comerciante das campanhas publicitárias dos fabricantes e dos produtores somente vinculará o comerciante quando contiver todos os elementos essenciais para a celebração do futuro contrato - mencionando a coisa e o preço, prescindindo, apenas, de aceitação.

Direito Civil. Seguro. Suicídio. Acidente Pessoal. Cláusula que afasta o suicídio da cobertura do seguro. Ineficácia diante da informaçāo anterior prestada ao segurado de que o seguro cobriria a morte por qualquer causa. Veiculação que obriga o contratante. De todo o modo, o suicídio não premeditado está incluído na espécie "acidentes pessoais". Prova da premeditação a cargo da seguradora, que deste ônus não se desincumbiu. Súmulas 105 do STF e 61 do STJ. Precedentes jurisprudenciais. Proporcionalidade na divisão da responsabilidade prevista apenas em convênio firmado entre seguradoras, sem a interveniência da estipulante ou do segurado. Obrigação única da companhia seguradora que firmou o convênio perante o beneficiário do segurado falecido. Apelo da Ré improvido. Provido o da Autora. (6fls.) (Apelação Cível no. 70000342790, Quinta Câmara Cível, Tribunal de Justiça do RS, Relator: Carlos Alberto Bencke, Julgado em 30/03/2000).

Ocorre que, em geral, as campanhas publicitárias levadas a efeito pelo fabricante não contêm informaçöes sobre o preço dos produtos e serviços ofertados ao público, o que acaba desvinculando o comerciante pela mensagem publicitária. No entanto, tendo em vista a solidariedade apresentada pelo novo regime dos vícios dos produtos e serviços estabelecidos pelo Código de Defesa do Consumidor quanto aos fornecedores, frente às disparidades decorrentes das indicaçöes nos recipientes, embalagens ou mensagens publicitárias, não está o consumidor desprotegido ${ }^{92}$ :

Art. 18. Os fornecedores de produtos de consumo duráveis ou não duráveis respondem solidariamente pelos vícios de qualidade ou quantidade que os tornem impróprios ou inadequados ao consumo a que se destinam ou thes diminuam o valor, assim como por aqueles decorrentes da disparidade, com as indicações constantes do recipiente, da embalagem, rotulagem ou mensagem publicitária, respeitadas as variações decorrentes de sua natureza, podendo o consumidor exigir a substituição das partes viciadas. (grifo nosso)

92 AMARAL JR., Alberto. O princípio da vinculaçäo da mensagem publicitária. In: Revista de Direito do Consumidor, 14, p. 50 . 
A idéia básica do Código de Defesa do Consumidor é a responsabilidade do organizador da cadeia no comércio normal, segundo os arts. $14^{93}$ e $20^{94}$, de modo a impor a este fornecedor a responsabilidade pelas falhas ocasionadas no âmbito dos fornecedores diretos e indiretos. O tema é de grande importância, eis que evita os escapismos dos fornecedores, mediante a exoneração por "culpa de terceiro", "uma vez que esse fornecedor-ajudante-de-cadeia de fornecimento não mais é terceiro ${ }^{95}$.

Consumidor - veículo importado que apresenta defeitos na sua fabricação - responsabilidade solidária do fabricante e da concessionária - direito do consumidor ao abatimento proporcional do preço ou à troca por outro automóvel novo - inteligência do art. 18 , parágrafo $1^{\circ}, 1$ da Lei 8.078/90. Apresentando veículo importado defeitos na sua fabricação, respondem solidariamente por tais vícios, na qualidade de fornecedora, a concessionária e o fabricante, pois, considerando-se que os defeitos apareceram no veículo somente 10 meses após sua utilização, não se pode afastar eventual descuido ou até troca de peças ocorridos no interior da concessionária. Assim, tem o comprador o direito ao abatimento proporcional do preço ou à troca por um outro automóvel novo, segundo estabelece o art. 18, parágrafo $1^{\circ}$, I da Lei 8.078/90 (T)RJ, 17 Câm. - ApCiv 9.740/2001 - j. 05.09.2001 - rel. Des. Raul Celso Lins e Silva - RT 801/ 343).

A responsabilidade, portanto, deste organizador, é geral, de qualidade adequação e segurança ${ }^{96}$, ressaltando que a doutrina brasileira vem

93 Aft. $14 \mathrm{CDC}$. O fornecedor de serviços responde independentemente da existência de culpa, pela reparaçăo dos danos causados aos consumidores por defeitos relativos à prestação dos serviços, bem como por informações insuficientes ou inadequadas sobre stı fruição e riscos. (...)

34 Art, 20 CDC. O fornecedor de serviços responde pelos vícios de qualidade que os tomem impróptos ao consumo ou thes diminuam o valor, assim como por aqueles decorrentes da disparidade com as indicaçoes constantes da oferta ou mensagem publicitária, podendo o consumidor exigir, altemativamente e à sua escolha: 1 - a reexecução dos serviços, sem custo adicional e quando cabível; II -.. a restituição imediata da quantia paga, monetariamente atualizada, sem prejuizo de eventuais perdas e danos; lll - o abatimento proporcional do preço. (...)

95 MARQUES, Cláudia Lima. Contratos no código de defesa do consumidor: o novo regime das relações

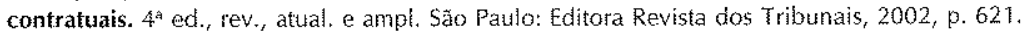

96 Segundo Cláudia Lima Marques, "no sistema do CDC, a responsabilidade deste organizador é imposta em termos claros: é de qualidade adequação (arts. 18 e 20), é de qualidade segurança (art. 14, caput), é solidária e sem culpa (arts. 14, 18 e 20 - exceção feita ao protissional hberal pelo parágrafo quarto do art. 14). Quebra-se, assim, a summa divisio entre a responsabilidade contratual e a extracontratual stricto sensu: há uma responsabilidade geral de qualidade adequaçāo e segurança”. MARQUES, Cláudia Lima. Contratos no código de defesa do consumidor: o novo regime das relaçōes contratuais. $4^{\mathrm{a}}$ ed, rev., atual. e ampl. São Paulo: Editora Revista dos Tribunais, 2002, p. 621. 
considerando o fulcro da responsabilidade a expectativa legítima, manifesta pela confiança que despertou nos consumidores. A jurisprudência já, há tempo, aplica os conceitos de responsabilidade amparada na confiança:

Direito do consumidor - filmadora adquirida no exterior - defeito da mercadoria - responsabilidade da empresa nacional da mesma marca (Panasonic) - economia globalizada propaganda - proteção ao consumidor - peculiaridades da espécie - situaçöes a ponderar nos casos concretos - nulidade do acórdão estadual rejeitada, porque suficientemente fundamentado - recurso conhecido e provido no mérito, por maioria. I - Se a economia globalizada não mais tem fronteiras rígidas e estimula e favorece a livre concorrência, imprescindível que as leis de proteção ao consumidor ganhem maior expressão em sua exegese, na busca do equilíbrio que deve reger as relações jurídicas, dimensionando-se, inclusive, o fator risco, inerente à competitividade do comércio e dos negócios mercantis, sobretudo quando em escala internacional, em que presentes empresas poderosas, multinacionais, com filiais em vários países, sem falar nas vendas hoje efetuadas pelo processo tecnológico da informática e no forte mercado consumidor que representa o nosso País. II - O mercado consumidor, não há como negar, vê-se hoje "bombardeado" diuturnamente por intensa e hábil propaganda, a induzir a aquisição de produtos, notadamente sofisticados de procedencia estrangeira, levando em linha de conta diversos fatores, dentre os quais, e com relevo, a respeitabilidade da marca. 111 - Se empresas nacionais se beneficiam de marcas mundialmente conhecidas, incumber Ihes responder também pelas deficiências dos produtos que anunciam e comercializam, não sendo razoável destinar-se ao consumidor as consequêencias negativas dos negócios envolvendo objetos defeituosos. IV - Impōe-se, no entanto, nos casos concretos, ponderar as situações existentes. $V$ Rejeita-se a nulidade argüida quando sem lastro na lei ou nos autos (ST) - 4a T. - Resp. 63981/SP - rel. Min. Aldir Passarinho Júnior - j. 11.04.2000).

Entretanto, a publicidade só terá efeitos os do art. 30 do CDC - como oferta - se for veiculada por aquele que fechará efetivamente o contrato. Por óbvio que o comerciante está sendo beneficiado pela publicidade veiculada pelo fabricante, mesmo aquela que não contém o preço do produto (essencial da compra e venda), e sim somente suas qualidades, de modo que nāo se trata 
de uma oferta própria ao consumidor, apta a iniciar a formação do contrato, nos moldes do dispositivo supracitado. O comerciante fará sua própria oferta ao consumidor, podendo esta ser diferente daquela do fabricante ${ }^{97}$.

De ressaltar, no entanto, que a publicidade será considerada enganosa ou abusiva independentemente da vontade especifica dolosa, ou que a aproximação entre fornecedor e consumidor tenha sido com o intuito direto de vender, de comerciar, bastando, somente, a atividade da publicidade como determinação soberana e profissional do fornecedor e sob o risco profissional deste, em caso de falha, erro ou culpa de terceiro da cadeia organizada ou contratada por ele próprio de fornecedores auxiliares ${ }^{98}$.

Contrato. Efeito da publicidade na formação do negócio. Compra e venda de imóvel. Propaganda lançada no mercado em que constava a garantia de financiamento para o comprador. Interpretação do art. 30 do CDC, em cotejo com art. 1.080 do Código Civil. A publicidade, assim como quaisquer outras informações veiculadas, obrigam ofertante e integram o contrato. Embargos infringentes rejeitados, por maioria. (Embargos Infringentes n. 599212396, Décimo Grupo de Câmaras Cíveis, Tribunal de Justiça do RS, Relator: José Aquino Flores de Camargo, Julgado em 28/05/1999).

Antonio Junqueira de Azevedo, em estudo a respeito da boa-fé na formação do contrato, conclui que o dever de indenizar na doutrina brasileira é encarado do lado da máfé, de modo que é somente responsável por perdas e danos aquele que agiu de má-fé na fase de formação contratual, devendo, portanto, responder pelo resultado. De ressaltar que os deveres violados na culpa in contrahendo são os secundários, e não os principais, eis que não houve negócio jurídico, o que vale dizer sejam indenizados, somente, via de regra, os danos resultantes da confiança na realização do negócio jurídico.

Por fim, relevante a transcrição da decisão proferida em processo que julgou como enganosa a propaganda veiculada por agência de turismo, a qual não foi confirmada em contato telefônico com o fornecedor, tampouco em adendo constante no contrato possível e futuramente firmado entre as partes. A defesa da agência consistia na inexistência de contrato firmado - frente à desvelada

9* Cláudia Lima Marques ressalta que surgirão dúvidas na Jurisprudência acerca da vinculação para o comerciante frente à oferta veiculada pelo fabricante, em relaçāo ao art. 30 do CDC. Entende que não será necessária a proteçăo do consumidor em referidos casos, eis que encontrará sua tutela no novo e amplo regime de vício de informação e de vicio de adequação dos arts. 18 e ss. do CDC. Marques, Cláudia Lima. Contratos no código de defesa do consumidor: o novo regime das relaçōes contratuais. $4^{\text {a }}$ ed., rev., atual. e ampl. São Paulo: Editora Revista dos Tribunais, 2002, p. 633.

9 MARQUES, Cládia Lima. Contratos no código de defesa do consumidor: o novo regime das relações contratuais. $4^{2}$ ed., rev., atual. e ampl. São Paulo: Editora Revista dos Titíunais, 2002, p. 629. 
discrepância entre oferta e reais condições do objeto a contratar - o que foi de pronto afastado pelo Magistrado, tendo em vista que "a obrigação nasceu a partir da veiculação da propaganda, no exato momento em que a consumidora manifestou a respectiva aceitaçāo ${ }^{99}$ ". Inolvidáveis trechos da sentença, que acabou por condenar a Requerida a possibilitar à consumidora a viagem veiculada:

(...) O anúncio não deixa a mínima margem para dúvidas. Foi ofertado um cruzeiro pelo Nordeste, conhecendo Fernando de Noronha, Natal, Recife, Maceió, Salvador, Morro de São Paulo (Bahia), Il héus, Porto Seguro, Angra dos Reis e Santos, pelo preço de $\bigcup \$ 640,00$ ou vinte parcelas de $\bigcup \$ 43,83$, a bordo do Funchal, "o mais aconchegante navio português", com saídas semanais a partir de 16 de dezembro, com validade até 03 de setembro de 1994. Se o roteiro não era completo e para conhecer os mesmo lugares precisaria o turista comprar pacotes de dois ou mais roteiros, e os locais eram aleatórios pela diversidade dos roteiros e tempo de duração, tudo deveria ter sido informado no mesmo anúncio, porque "toda informação ou publicidade, suficientemente precisa, veiculada por qualquer forma ou meio de comunicação com relação a produtos e serviços oferecidos ou apresentados, obriga o fornecedor que a fizer veicular ou dela se utilizar e integra o contrato que vier a ser celebrado", diz o art. 30 do Código de Defesa do Consumidor ${ }^{100}$. (grifo nosso)

\section{CONCLUSÃO}

Ruy Rosado de Aguiar Jr. coloca que a boa-fé é limitadora do direito subjetivo, muito embora sua finalidade principal seja a manutenção do vínculo, aperfeiçoado pelos princípios da confiança, da lealdade, da honestidade e da verdade. O Direito Brasileiro, ao inclinar-se para a realização desses valores, acompanha a tendência de moralismo contratual, presente hoje no Direito Comparado ${ }^{10 \%}$.

Pela boa-fé, a obrigação é entendida como ordem de cooperação, de modo que, para Cristoph Fabian, "credor e devedor não sejam apenas

\footnotetext{
99 Obrigação de fazer - erro na oferta publicitária - presunçảo de boa-fé do consumidor - vinculação da fornecedora ao roteiro da viagem e ao preço veiculado -.. Processo no. 840/95-6 - J.E.P.C. Central II Procon. Sentença publicada na Revista de Direito do Consumidor, 17, p. 264.

10) Obrigaçăo de fazer - erro na oferta publicitária - presunçăo de boa-fé do consumidor - vinculação da fornecedora ao roteiro da viagem e ao preço veiculado - Processo n. 840/95-6 - J.E.P.C. Central II Procon. Sentença publicada na Revista de Direito do Consumidor, 17, p. 263-5.

10i AGUIAR JÚNIOR, Ruy Rosado de. A boáfé nas relaçoes de consumo. In: Revista de Direito do Consumidor, 14, p. 27 .
} 
contratantes, e sim sejam colaboradores na consecução do objetivo comum ${ }^{102 "}$. No direito do consumidor, a boa-fé ainda tem uma função socioeconômica, garantindo comportamentos dos contratantes pelos quais cada um procura realizar seus fins ou expectativas do negócio. Quando seus interesses estão em contraposição, a boa-fé é pauta de orientação para conseguir harmonia o equilibrio entre os dois interesses ${ }^{103}$.

Foram trabalhados neste estudo a oferta, a proposta e a publicidade, tendo sido, desde logo, esclarecidos os conflitos que podem surgir da diferença entre oferta e proposta, tendo em vista a existência da oferta do Código de Defesa do Consumidor e a da proposta do Código Civil. Resta bem clara a diferença entre ambas na finalidade, eis que existem as ofertas voltadas ao consumidor (varejo) e as ofertas voltadas aos comerciantes (atacado).

Após a aceitação da oferta pelo consumidor, a natureza do vínculo obrigacional ligando-o ao fornecedor transforma-se em vínculo de natureza contratual, se bem que suas características continuem as mesmas e apenas acrescente-se a possível exigibilidade da prestação principal. Antônio Junqueira de Azevedo coloca que a relação jurídica entre os pré-contratantes terá eficácia pelo lado negativo, ou patológico, isto é, "pelo lado do dever de não se comportar de forma socialmente condenável. Esse dever é sancionado pela ação de indenização do art. 159 do CC $^{104 " .}$.

De mencionar trecho do parecer de Alcides Tomasetti Jr. em questāo típica de publicidade enganosa que acabou vinculando as partes, para corroborar o vertido até o momento:

A fornecedora Mesbla S/A, em razão de alegado erro, aliás, inescusável, veiculou descuidadamente publicidade de um produto em circunstâncias suficientemente precisas para obrigar-se. Uma vez declarado o anúncio da oferta, os riscos correspondentes correm por conta do fornecedor, pois que estão reconhecidos, de lege data, a vulnerabilidade do consumidor e o seu direito subjetivo básico no sentido de ser resguardado dos riscos no mercado de consumo $(C D C$, arts. $4^{\circ}, 1$ e $\left.6^{\circ}, 1\right)^{105}$

102 FABIAN, Cristoph. O dever de informar no direito civil. São Paulo: Editora Revista dos Tribunais, $2002, p$. 61 .

303 SILVA, Agathe Schmidt da. Cláusula geral de boa-fé nos contratos de consumo. In: Revista de Direito Civil, v. 17, n. 151, jan-mar./1996, p. 146.

${ }^{104}$ AZEVEDO, Antonio Junqueira de. A boa-fé na formaçāo dos contratos. In: Revista de Dreito do Consumidor, 03, p. 79.

105 TOMASETTI IR., Alcides. Oferta contratual em mensagem publicitária - regime do direito comum e do Código de Proteçảo do Consumidor. In: Revista de Direito do Consumidor, 04, p. 252. 
De concluir que o juiz pode utilizar critérios para apurar a conduta das partes - fornecedor e consumidor - no decorrer das negociações, a fim de obter a melhor resposta frente ao problema da culpa in contrahendo: Diante da confiança criada e prejuizos sofridos, diante da causa e efeito entre negociação e prejuízo (nexo de causalidade) e diante da ausência de má-fé do prejudicado - três pressupostos -, o juiz pode arbitrar um quantum de indenização ${ }^{106}$, tendo em vista a falta cometida pela parte anunciante e que resolve não cumprir com a publicidade veiculada e que, necessariamente, acaba por vincular as partes.

Por fim, conclui Antônio Junqueira de Azevedo, a respeito da atribuição da indenização originada na ruptura das negociaçōes, cujo objetivo nada mais é do que divisar os riscos originados em qualquer negócio jurídico:

A responsabilidade pelos danos resultantes de fatos na formação contratual, à semelhança de outros casos de responsabilidade não fundada na culpa - nem no inadimplemento - estaria fundamentada no princípio maior, de solidariedade social, que justifica a distribuição eqüitativa dos prejuízos ${ }^{107}$.

\section{REFERÊNCIAS}

AGUIAR JÚNIOR, Ruy Rosado de. A boa-fé nas relações de consumo. In: Revista de Direito do Consumidor, 14, p. 20-27.

ALMEIDA COSTA, Mário Júlio de. Contrato-promessa - uma síntese do regime vigente. $7^{a}$ ed., rev. e actual., Coimbra, Almedina, 2001.

- Direito das obrigações. $9^{2}$ ed., rev. e aum., Coimbra: Livraria Almedina, 2001.

- Responsabilidade civil pela ruptura das negociações preparatórias de um contrato. Coimbra, Coimbra Editora Limitada, 1984.

AMARAL JR., Alberto. O princípio da vinculação da mensagem publicitária. In: Revista de Direito do Consumidor, 14, p. 41-51.

AZEVEDO, Antonio Junqueira de. A boa-fé na formação dos contratos. In: Revista de Direito do Consumidor, 03, p. 78-87.

. Negócio jurídico - existência, validade e eficácia: 4a ed., atual. de acordo com o novo Código Civil (Lei n. 10.146, de 10.01.2002). São Paulo: Saraiva, 2002.

106 AZEVEDO, Antonio Junqueira de. A boa-fé na formação dos contratos. In: Revista de direito do consumidor, $03, p .87$.

${ }^{107}$ AZEVEDO, Antonio Junqueira de. A boa-fé na formação dos contratos. In: Revista de Direito do Consumidor, 03, p. 87. 
BETT, Emilio. Teoria general del negocio jurídico. Trad. espanhola, Ed. Rev. de Derecho Privado, Madri.

BITTAR, Carlos Alberto. O controle da publicidade: sancionamentos a mensagens enganosas e abusivas. In: Revista de Direito do Consumidor, 04, p. 126-31.

BRASIL... Constituição Federal da República Federativa do Brasil. Brasil: Senado Federal, 2001.

CANARIS, Claus-Wilhelm. Pensamento sistemático e conceito de sistema na ciência do direito. 2 ed. Lisboa: Calouste Gulbenkian, 1996.

CENEVIVA, Walter. Publicidade e direito do consumidor. São Paulo: Editora Revista dos Tribunais, 1991.

CHAISE, Valéria Falcão. A publicidade como causa de obrigação. Trabalho de dissertação de Mestrado, orientador Dr. Luis O. Andomo, Universidade Federal do Rio Grande do Sul: Porto Alegre, 1998.

CHAVES, Antônio. Responsabilidade pré-contratual. Rio de Janeiro: Companhia Editora Forense, 1959.

CRISAFULLI, Vincent. Le risque "R.C. produits" du fabricant, em droit français. In: Revue Trimestrielle de Droit Commercial, t. XXVII, 1974, p. 413-38.

FABIAN, Cristoph. O dever de informar no direito civil. São Paulo: Editora Revista dos Tribunais, 2002.

FRADERA, Vera Maria Jacob de. A interpretação da proibição de publicidade enganosa ou abusiva à luz do princípio da boa-fé: o dever de informar no Código de Defesa do Consumidor. In: Revista de Direito do Consumidor, 04, p. 173-91.

. O dever de informar do fabricante. In: Revista dos Tribunais, 656, junho de 1990, pág. 53-71.

GAZZONI, Francesco. Il contratto preliminare - estratto da If contratto in generale Trattato di diritto privato, diretto da Mario Bessone - volume IX - Tomo II. G. Giappichelli Editore, Torino, 1998.

GHERSI, Carlos A. (Dir.). Contratos 2 - problemática moderna. Mendoza: Ediciones Jurídicas Cuyo, 1996.

GOMES, Orlando. Responsabilidade civil do fabricante. In: Revista de Direito Civil, Imobiliário, Agrário e Empresarial, 32, ano 9, abril/junho 1985, p. 12-21.

- Transformaçōes gerais do direito das obrigações. $2^{\text {a }}$ ed., aument. São Paulo: Editora Revista dos Tribunais, 1980.

GRAU, Eros Roberto. Interpretando o Código de Defesa do Consumidor: algumas notas. In: Revista de Direito do Consumidor, 05, p. 183-189.

GRINOVER, Ada Pelegrini (et. al.). Código brasileiro de defesa do consumidor comentado pelos autores do anteprojeto. $7^{\text {a }}$ ed. Rio de Janeiro: Forense Universitária, 2001.

GUERRA FILHO, Willis Santiago. Direitos subjetivos, direitos humanos e jurisprudência dos interesses (relacionados com o pensamento tardio de Rudolph von thering). In: Arquivos do Ministério da Justiça, Brasília, 47(183): jan/jun de 1994, p. 13558.

JHERING, Rudolf Von. A evolução do direito. Vertido da tradução francesa de $O$. de Meulenaere, por Abel D'Azevedo. Lisboa, J/Bastos, SD, 1971.

. Oeuvres choisies. Trad. O. De Meulenaere, t. 2, Paris, p. 1-100.

LARENZ, Karl. Derecho Civil - Parte General. Trad. Miguel Izquierdo y Macias --. Picavea. Madri: Edersa, 1978. 
- Metodologia da Ciência do Direito. $3^{a}$ ed., Lisboa: Fundação Calouste Gulbenkian, 1997.

LÔBO, Paulo Luiz Netto. A informação como direito fundamental do consumidor. In: Revista de Direito do Consumidor, 37, p. 59-76.

LORENZETTI, Ricardo Luis. Analisis crítico de la autonomia privada contractual. In: Revista de Direito do Consumidor, 14, p. 5-19.

LORENZETTI, Ricardo Luis. La oferta como aparencia y la aceptación basada en la Confianza. In: Revista de Direito do Consumidor, 35, p. 9-38.

MARQUES, Cláudia Lima; BENJAMIN, Antonio Herman V.; e MIRAGEM, Bruno. Comentários ao Código de Defesa do Consumidor: arts. $1^{\circ}$ a 74 - aspectos materiais. São Paulo: Editora Revista dos Tribunais, 2003.

MARQUES, Cláudia Lima. Contratos no código de defesa do consumidor: o novo regime das relações contratuais. $4^{\circ}$ ed., rev., atual. e ampl. São Paulo: Editora Revista dos Tribunais, 2002.

- Vinculação própria através da publicidade? A nova visão do Código de Defesa do Consumidor. In: Revista de Direito do Consumidor, 10, p. 7-20.

MARTINS-COSTA, Judith. A ambigüidade das peças publicitárias e os princípios do Código de Defesa do Consumidor. In: Revista da Ajuris, p. 113-30.

. A boa-fé no direito privado: sistema e tópica no processo obrigacional. São Paulo. Editora Revista dos Tribunais, 2000.

. Contratos internacionais - cartas de intenção no processo formativo da contratação internacional - graus de eficácia dos contratos - responsabilidade pré-negocial. In: Revista Trimestral de Direito Público, 05, 1992, p. 207-24.

MAZEAUD, Henri. La responsabilité civile du vendeur-fabricant. In: Revue Trimestrielle de Droit Civit, t. 63, 1955, p. 611-21.

MENEZES CORDEIRO, António Manuel da Rocha e. Da boarfé no direito civil. Coimbra: Almedina, 2001. 1994.

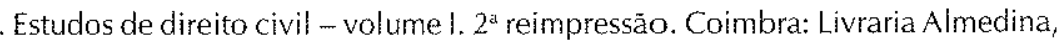

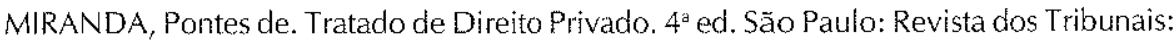
1984. T. 38.

MOTA PINTO, Carlos Alberto. A responsabilidade pré-negocial pela não conclusão dos contratos. In: Boletim da Faculdade de Direito da Universidade de Coimbra, supl. 14, 1966, p. 143-252.

PASQUAL, Cristina Stringari. Estrutura e vinculação da oferta no Código de Defesa do Consumidor. Trabalho de dissertação de Mestrado, orientadora Profa. Dra. Cláudia Lima Marques, Universidade Federal do Rio Grande do Sul: Porto Alegre, 2003.

PASQUALOTTO, Adalberto de Souza. O regime obrigacional da publicidade nas relações de consumo. Trabalho de dissertaçäo de Mestrado, orientador Dr. Nelson Nery Júnior, Universidade Federal do Rio Grande do Sul: Porto Alegre, 1995.

PEREIRA, Caio Mário da Silva. Responsabilidade Civil - de acordo com a Constituição Federal de 1988. $8^{3}$ ed., rev, e atual. Rio de Janeiro: Editora Forense, 1996.

POPP, Carlyle. Responsabilidade civil pré-negocial: o rompimento das tratativas. 1" ed., $3^{\text {a }}$ tir. Curitiba: Juruá, 2003.

PRATA, Ana. A tutela constitucional da autonomia privada. Livraria Almedina: Coimbra, 1982. 
RAIZER, Ludwig. O futuro do direito privado. In: Revista da Procuradoria Geral do Estado, Porto Alegre, 1979, 9 (25), p. 11-30.

REALE, Miguel. Experiência e cultura. Campinas: Bookseller, 1999.

. Fontes e modelos do direito: para um novo paradigma hermenêutico. São Paulo: Saraiva, 1994.

. O projeto do novo Código Civil. São Paulo: Saraiva, 1999.

. Visão geral do projeto de código civil. In: Revista dos Tribunais, ano 87, v. 752, junho de 1998, p. 22-30.

ROCHA, Sílvio Luis Ferreira da. Erro na oferta no Código de Defesa do Consumidor. In: Revista de Direito do Consumidor, 09, p. 58-62.

ROPPO, Enzo. O contrato. Coimbra, Livraria Almedina, 1988.

SILVA, Agathe Schmidt da. Cláusula geral de boa-fé nos contratos de consumo. In: Revista de Direito Civil, v. 17, n.151, 1996, p. 146.

SILVA, Almiro do Couto e. Responsabilidade pré-negocial e culpa in contrahendo no Direito Administrativo. In: Revista Brasileira de Direito Comparado, Rio de Janeiro, n. 18,2000, p. 206.

SILVA, Clóvis Veríssimo do Couto e. A obrigação como processo. São Paulo: José Bushatsky, 1976.

SILVA, João Calvão da. Sinal e contrato-promessa. $9^{a}$ ed., rev. e aument., Coimbra, Almedina, 2002.

STIGLITZ, Gabriel A. Protección jurídica del consumidor. $2^{\text {a }}$ ed., actual. Buenos Aires: Depalma, 1990.

TOMASETTI IR., Alcides. Execução do contrato preliminar. Universidade de Săo Paulo, Curso de Pós-Graduação em Direito Civil, São Paulo, 1982.

. O objetivo de transparência e o regime jurídico dos deveres e riscos informação nas declarações negociais para consumo. In: Revista de Direito do Consumidor, 04, p. 51-90.

Oferta contratual em mensagem publicitária - regime do direito comum e do Código de Proteção do Consumidor. In: Revista de Direito do Consumidor, 04, p. 241-77. 